\title{
Pengaruh Penambahan Tepung Maizena Terhadap Mutu Nugget Ikan Gabus (Channa Striata)
}

\author{
Diah Ratnasari $^{* 1}$, Yuniarti Dewi $\mathbf{R}^{2}$, Lupi Purniasih ${ }^{3}$ \\ Program Studi Ilmu Gizi, Fakultas Ilmu Kesehatan, Universitas Muhadi Setiabudi Brebes, Indonesia \\ Email: 1*diahratna1708@gmail.com, \\ 2yuniartidewi.rahmawati@gmail.com, ${ }^{3}$ lupipurniasih97@gmail.com,
}

\begin{abstract}
ABSTRAK
Tepung maizena adalah pati yang didapatkan dari endosperma biji jagung, mempunyai ciri khas berupa warna putih dan tekstur halus.Ikan gabus merupakan salah satu jenis ikan air tawar yang memiliki kandungan protein yang tinggi. Selain itu ikan gabus memiliki daging yang banyak, pengolahan ikan gabus sebagai nugget agar tidak cepat mengalami pembusukan dengan penambahan tepung maizena agar tekstur dan rasa pada ikan gabus memiliki ciri khas. Penelitian ini bertujuan untuk melihat pengaruh penambahan tepung maizena terhadap nugget ikan gabus (Channa striata) terhadap mutu organoleptik kadar proteindan kadar air. Jenis penelitian ini bersifat eksperimental yaitu dengan rancangan percobaan yang digunakan dalam percobaan ini adalah rancangan acak lengkap (RAL), yang terdiri dari ikan gabus dan tepung maizena dengan 3 kali perlakuan dan pengulangan. P1 5\%:95\%, P2 10\%:90\% dan P3 15\%:85\%. Data Variabel kimia diperoleh dianalisis menggunakan uji kadar protein dan Uji organoleptik dianalisi dengan menggunakna sidik ragam (ANOVA). Berdasarkan hasil mutu organoleptik nugget ikan gabus pada porposi tepung maizena terhadap warna nugget P1 (5\%), pada rasa Pl (5\%), Aroma Pl (5\%) dan pada tekstur P3(15\%) kadar protein nugget ikan gabus dengan penambahan tepung maizena pada perlakuan P1 dengan penambahan tepung maizena 5\% : ikan gabus $85 \%$ menghasilkan protein 15,86\%.dan kadar air $1,62 \%$.
\end{abstract}

Kata Kunci : Tepung Maizena, Nugget, Ikan Gabus, Uji Organoleptik.

\begin{abstract}
Cornstarch is starch obtained from the endosperm of corn kernels, which has a characteristic white color and fine texture. Snakehead fish is a type of freshwater fish that has a high protein content. In addition, snakehead fish has a lot of meat, processing snakehead fish as nuggets so that it does not quickly decompose with the addition of cornstarch so that the texture and taste of snakehead fish has a characteristic. This study aims to determine the effect of adding cornstarch to snakehead fish nuggets (Channa striata) on organoleptic quality and protein content. This type of research is experimental, namely the experimental design used in this experiment is a completely randomized design (CRD), consisting of snakehead fish and cornstarch with 3 treatments and repetitions. P1 5\%: 95\%, P2 10\%: 90\% and P3 15\%: 85\%. Chemical variable data obtained were analyzed using protein content test and organoleptic test was analyzed using variance fingerprint (ANOVA). Based on the results of the organoleptic quality of snakehead fish nuggets on the proportion of cornstarch to the color of the nugget P1 (5\%), the taste of P1 (5\%), aroma of Pl (5\%) and texture of P3 (15\%) protein content of snakehead fish nuggets with The addition of cornstarch in treatment P1 with the addition of 5\% cornstarch: $85 \%$ snakehead fish produced $15.86 \%$ protein.
\end{abstract}

Keywords: Cornstarch, nugget, snakehead fish, organoleptic test

\section{PENDAHULUAN}

Nugget merupakan makanan yang bahan dasarnya dari daging maupun dari biji-bijian yang mengandung protein hewani atau nabati, nugget salah satu makanan yang populer dikalangan masyarakat karena rasa yang enak, gurih penyajiannya yang praktis dan memiliki nilai gizi yang tinggi. Kehidupan masyarakat moderen yang ingin serba praktis membuat nugget menjadi makanan yang biasa digunakan sebagai lauk selingan atau camilan. Penerimaan masyarakat terhadap produk nugget saat ini semakin meningkat, hal ini dapat dilihat banyaknya produk nugget yang dijumpai dari berbagai macam bentuk dan bahan baku seperti nugget ayam, sapi dan ikan.[1] Nugget merupakan makanan yang praktis, misalnya bisa digunakan untuk menu sarapan dengan gizi yang cukup tinggi. Sarapan dengan menu padat gizi diketahui dapat meningkatkan prestasi belajar .[2] 
Masyarakat Indonesia mengenal tepung maizena biasa digunakan dalam pembuatan sponge cake dan puding yang menghasilkan tekstur lembut dan halus, sedangkan pada kue dapat menghasilkan kue yang renyah. Tepung maizena juga digunakan sebagai pengental dan bahan pengikat ataupun bahan pengsis dalam pembuatan suatu makanan. Salah satumya adalah nugget yang berfungsi sebagai bahan pengikat. Penggunaan ikan sebagai bahan baku pembuatan nugget memiliki keunggulan yaitu ikan memiliki jaringan ikat sedikit sehingga tekstur nugget yang dihasilkan akan lebih lembut dan kenyal dibandingkan dengan daging ayam, daging sapi, ikan mengandung asam lemak tidak jenuh yang baik bagi kesehatan. Salah satu ikan yang akan digunakan dalam pembuatan nugget adalah ikan gabus.Menurut Standar Nasional Indonesia (SNI), dalam pembuatan nugget batas maksimum kadar air adalah $60 \%$ untuk mendapatkan kadar air yang mendekati Standar Nasional Indonesia pada nugget, maka dilakukan penambahan bahan pengikat yaitu tepung maizena dengan menggunakan variasi konsentrasi 5\%, 10\% dan 15\% [3]. Tepung maizena adalah hasil olahan dari sari pati jagung, 100gram tepung maizena yang mengandung energi $343 \mathrm{kkal}$, karbohidrat $85 \mathrm{gr}$, protein $0,30 \mathrm{gr}$, lemak 0 gr [4].

Ikan gabus yang memiliki manfaat antara lain meningkatkan kadar albumin dan daya tahan tubuh, mempercepat proses penyembuhan pascaoperasi dan mempercepat penyembuhan luka dalam atau luka luar, mempunyai kandungan protein yang cukup tinggi yaitu sebesar 25,2\%, dan juga mengandung albumin yang tidak dimiliki oleh ikan lainnya seperti ikan lele, ikan gurami, ikan nila, ikan mas dan sebagainya. Albumin adalah protein yang dapat larut air serta dapat teroagulasi oleh panas, ikan gabus mempunyai kandungan albumin sebesar 62,24 g/kg (6,2\%). Kandungan asam amino esensial dan asam amino nonesensial pada ikan gabus memiliki kualitas yang jauh lebih [5] baik dari telur. Kadar protein yang dimiliki oleh ikan gabus dapat dihitung dari setiap gram bagian yang dapat dimakan ikan tersebut. Setiap 100 gram ikan gabus 25,2 gram, yang berarti lebih tinggi kadar proteinnya dari pada jenis ikan lainnya, serta dalam 100 gram ikan terkandung energi $116 \mathrm{kkal}$, lemak $1,7 \mathrm{gr}$, kalsium $62 \mathrm{mg}$, fosfor $178 \mathrm{mg}$, besi 0,9 mg. [6] Nilai gizi pada ikan gabus cukup tinggi dan juga mengandung berbagai mineral dan vitamin A, dengan demikian ikan gabus sangat potensial untuk dikembangkan dalam industri pangan [7].

Hasil Penelitian Ofrianti dan Wati (2013) dalam "Pengaruh Variasi konsentrasi Tepung Kedelai sebagai Bahan pengikat Terhadap kadar air dan mutu Organoleptik Nugget Ikan Gabus", diketahui menggunakan bahan pengisi tepung kedelai diperoleh penggunaan bahan pengisi sebanyak 15\% sebagai perlakuan terbaik terhadap sifat organoleptik. [8] Ria Kumala (2011) "Kajian komposisi kimia, kualitas fisika dan organoletiptik Ducknuggetdengan filler tepung maizena pada proposi yang berbeda" Penambahan filler pada taraf $15 \%$ memberikan hasil terbaik pada kualitas kimia dan fisika sedangkan penambahan filler tepung maizena pada taraf $10 \%$ memberikan hasil terbaik pada uji organoleptik [9].

\section{BAHAN DAN METODE}

Desain penelitian: Jenis penelitian ini bersifat eksperimental yaitu dengan rancangan percobaan yang digunakan dalam percobaan ini adalah rancangan acak lengkap (RAL), penelitian dilakukan pada bulan Juli sampai Agustus 2020. Pembuatan nugget ikan gabus dan penelitian analisis uji organoleptik dilakukan di Laboratorium Penyelenggaraan Makanan Universitas Muhadi Setiabudi Brebes. Pengujian kandungan protein dilakukan di laboratorium BP2MHP Semarang.

Populasi dan sampel penelitian uji organoleptik akan di uji dengan 25 mahasiswa yang menjadi panelis di kampus Universitas Muhadi Setiabudi Brebes meliputi warna, aroma, rasa, dan tekstur dari nugget ikan gabus. Alat yang digunakan terdiri dari 25 orang yang disebut panel, orang yang bertugas sebegai panel disebut panelis. Kriteria inklusi dan eksklusi pada Panelis dalam penelitian ini adalah panelis tidak terlatih yaitu mahasiswa Universitas Muhadi Setiabudi Brebes sebanyak 25 orang, kriteria panelis dalam penelitian ini diantaranya tidak sedang sakit/tidak enak badan, bersedia menjadi panelis, dan bisa bekerjasama

Variabel bebas pada penelitian ini adalah proporsi nugget ikan gabus dengan penambahan tepung maizena, sedangkan variable terikatnya adalah kadar protein dan uji organoleptic. Alat dan bahan yang digunakan adalah formulir penelitian, alat tulis dan air minum

JIGK Vol. 02, No. 02, Februari 2021: 7 - 14 
kemasan sebagai penetralisir rasa. Sedangkan bahan yang digunakan adalah nugget ikan gabus dengan tambahan tepung maizena.

Kadar air dianalisis menggunakan metode oven. Cawan yang digunakan dioven terlebih dahulu selama 2 jam pada suhu $105{ }^{\circ} \mathrm{C}$, kemudian didinginkan dalam eksikator selama setengah jam, lalu ditimbang (A). Sampel ditimbang (B), setelah itu cawan berisi sampel dikeringkan dalam oven pada suhu $105{ }^{\circ} \mathrm{C}$ selama 8 jam kemudian didinginkan dalam eksikator selama setengah jam kemudian ditimbang. Analisis Data Variabel kimia diperoleh dianalisis menggunakan uji kadar protein dan Uji organoleptik dianalisi dengan menggunakna sidik ragam (ANOVA). Data yang sudah diperoleh dari penelusuran menggunakan dokumentasi dan berdasarkan hasil pengujian laboratorium akan diolah dan disajikan secara sistematis, Dalam memudahkan dan mempercepat proses pengolahan data, menggunakan komputerisasi dengan menggunakan program SPSS versi 22.

\section{Hasil Uji Organoleptik}

\section{HASIL DAN PEMBAHASAN}

Pengujian ini dilakukan oleh 25 panelis tidak terlatih dengan parameter warna, rasa, aroma, tekstur.

\section{1) Warna}

Berdasarkan hasil penelitian diketahui bahwa nugget ikan gabus dengan penambahan tepung maizena $15 \%$ memiliki nilai rata-rata tertinggi untuk mutu organoleptik (warna) nugget, dapat di lihat pada Tabel 1 bahwa rata-rata kesukaan terhadap warna dalam penambahan tepung maizena terhadap nugget ikan gabus memberikan kategori kecoklatan.

Tabel 1. Hasil Analisis Uji Organoleptik Terhadap Warna Nugget Ikan Gabus Dengan Penambahan Tepung Maizena 5\%, 10\% Dan 15\%

\begin{tabular}{lcccc}
\hline Perlakuan & \multicolumn{3}{c}{ Pengulangan } & Rata-rata \\
\cline { 2 - 4 } & \multicolumn{1}{c}{ I } & II & III & \\
\hline P1 (5\%) & 3,16 & 3,12 & 3,16 & 3,15 \\
P2 (10\%) & 2,84 & 3,28 & 3,20 & 3,10 \\
P3 (15\%) & 2,96 & 3,32 & 3,15 & 3,14 \\
\hline
\end{tabular}

Keterangan : P1 Tepung maizena 10gr : ikan gabus 190gr dengan rata-rata 3,15, P2 Tepung maizena 20gr : ikan gabus $180 \mathrm{gr}$ dengan rata-rata 3,10, P3 Tepung maizena 30gr : ikan gabus $170 \mathrm{gr}$ dengan rata-rata 3,14 .

Berdasarkan hasil penelitian diketahui bahwa nugget kan gabus dengan penambahan tepung maizena 5\% memiliki rata-rata tertinggi untuk mutu organoleptik (warna) nugget ikan gabus. dilihat bahwa rata-rata kesukaan terhadap warna dalam penambahan tepung maizena terhadap nugget ikan gabus memberikan kategori kecoklatan.Nugget pada dasarnya dilapisi tepung panir berwarna kuning sehingga ketikan proses penggorengan menyebabkan terjadinya reaksi pencoklatan (Maillard). Rata-rata penilaian panelis secara uji organoleptik terhadap warna berkisar skor 3,10-3,15 (kecoklatan).

Tabel 2 Hasil Analisis data Warna

\begin{tabular}{lll}
\hline Jenis Variabel yang diamati & Sig. & Total rata-rata \\
\hline Warna & 0,144 & 3,15
\end{tabular}

Hasil uji penambahan tepung maizena $(5 \%, 10 \%$ dan 15\%) tidak berpengaruh secara signifikan terhadap warna nugget ikan gabus, yang ditunjukan nilai $\mathrm{P}=0,144(\mathrm{P}>0,05)$.

Pada penelitian Yulianti, Andi Khairun Mutia (2018) menujukkan bahwa perbedaan kosentrasi tepung yang digunakan tidak berpengaruh secara signifikan terhadap nugget yang dihasilkan. 


\section{2) Rasa}

Hasil dari uji organoleptik dapat dilihat pada tabel sebagai berikut di bawah ini :

Tabel 3 Hasil Analisis Uji Organoleptik Terhadap Rasa Nugget Ikan Gabus Dengan Penambahan Tepung Maizena 5\%, 10\% Dan $15 \%$

\begin{tabular}{|c|c|c|c|c|}
\hline \multirow[t]{2}{*}{ Perlakuan } & \multicolumn{3}{|c|}{ Pengulangan } & \multirow[t]{2}{*}{ Rata-rata } \\
\hline & I & II & III & \\
\hline P1 5\% & 3,16 & 3,12 & 2,92 & 3,09 \\
\hline P2 $10 \%$ & 2,90 & 2,84 & 3,20 & 2,98 \\
\hline P3 $15 \%$ & 2,50 & 2,64 & 2,52 & 2,55 \\
\hline
\end{tabular}

Keterangan : P1 Tepung maizena 10gr : ikan gabus 190gr dengan rata-rata 3,09, P2 Tepung maizena $20 \mathrm{gr}$ : ikan gabus $180 \mathrm{gr}$ dengan rata-rata 2,98, P3 Tepung maizena 30gr : ikan gabus 170 gr dengan rata-rata 2,55 .

Dari Tabel 3 dapat dilihat bahwa rata-rata kesukaan terhadap rasa dalam penambahan tepung maizena terhadap nugget ikan gabus memberikan kategori renyah. diketahui bahwa nugget ikan gabus dengan penambahan tepung maizena $5 \%$ memiliki rata-rata tertinggi untuk mutu organoleptik (rasa) nugget ikan gabus. Dari Tabel .3 menujukan rata-rata skor penilaian panelis secara uji organoleptik terhadap rasa nugget ikan gabus antara 2,55-3,09 (renyah dan agak renyah). Berdasarkan Tabel.3 semakin tinggi kosentrasi tepung maizena yang digunakan tingkat kesukaan terhadap rasa nugget ikan gabus semakin menurun.

Tabel 4 Hasil Analisis Data Rasa

\begin{tabular}{lcc}
\hline Jenis Variabel yang diamati & Sig. & Total rata-rata \\
\hline Rasa & 0,006 & 2,8 \\
\hline
\end{tabular}

Hasil uji One-way ANOVAtepung maizena (5\%, $10 \%$ dan 15\%) berpengaruh secara signifikan terhadap rasa nugget ikan gabus, yang ditunjukan nilai $\mathrm{P}=0,006(\mathrm{P}<0,05)$, yang artinya ada hubungan penambahan tepung maizena dengan mutu organoleptik. Hal ini sejalan dengan penelitian yang dilakukan Yenni Ofrianti (2013) bahwa ada pengaruh terhadap mutu organoleptik terhadap rasa nugget ikan gabus. Rasa nugget yang paling banyak disukai yaitu nugget ikan gabus dengan kosentrasi $10 \%$.

\section{3) Aroma}

Hasil uji organoleptik dari aspek aroma dapat dilihat pada tabel dibawah ini:

Tabel 5. Hasil Analisis Uji Organoleptik Terhada Aroma Nugget Ikan Gabus Dengan Penambahan Tepung Maizena 5\%, 10\% Dan 15\%

\begin{tabular}{|c|c|c|c|c|}
\hline \multirow[t]{2}{*}{ Perlakuan } & \multicolumn{3}{|c|}{ Pengulangan } & \multirow[t]{2}{*}{ Rata-rata } \\
\hline & I & II & III & \\
\hline P1 (5\%) & 2,88 & 3,16 & 3,00 & 3,01 \\
\hline P2 (10\%) & 2,96 & 2,76 & 2,84 & 2,84 \\
\hline P3 (15\%) & 2,80 & 2,92 & 2,92 & 2,92 \\
\hline
\end{tabular}

Keterangan : P1 Tepung maizena 10gr : ikan gabus 190gr dengan rata-rata 3,01, P2 Tepung maizena $20 \mathrm{gr}$ : ikan gabus $180 \mathrm{gr}$ dengan rata-rata 2,84, P3 Tepung maizena 30gr : ikan gabus $170 \mathrm{gr}$ dengan rata-rata 2,92 .

Berdasarkan Tabel 5 hasil uji organoleptik aroma nugget ikan gabus dari penambahan tepung maizena diperoleh nilai rata-rata yaitu 2,84-3,01. Nilai rata-rata terendah aroma nugget ikan gabus didapat pada sempel P3 yaitu dengan penambahan tepung maizena 15\% yang mempunyai nilai rata-rata 2,8 agak amis. Nilai rata-rata tertinggi aroma nugget ikan gabus didapat pada perlakuan P1 yaitu dengan penambahan tepung maizena 5\% dengan rata-rata yaitu 3,01 dengan kategori amis. 
Tabel 6 Hasil Analisis Data Aroma

\begin{tabular}{lll}
\hline Jenis Variabel yang diamati & Sig. & Total rata-rata \\
\hline Aroma & 0,828 & 2,9 \\
\hline
\end{tabular}

Hasil uji statisstik, ditunjukan dengan nilai P-value (Sig.) 0,828 lebih dari 0,05. tepung maizena tidak memberi pengaruh terhadap aroma nugget ikan gabus dikarenakan tepung maizena adalah tepung yang tidak memiliki aroma khas ketika dibuat suatu olahan.

Berdasarkan penelitian Veni indrawati (2016) menjelaskan bahwa tidak berpengaruh aroma pada penambahan tepung maizena dan pure rumput laut terhadap kualitas somay dikarenakan pengaruh rentang yang terlalu pendek yaitu dari perlakuan $15 \%, 20 \%$, dan $25 \%{ }^{4}$

4) Tekstur

Hasil uji organoleptik dari aspek testur dapat dilihat pada gambar tabel ini sebagai berikut

Tabel.7 Hasil Analisis Uji Organoleptik Terhada Tekstur Nugget Ikan Gabus Dengan Penambahan Tepung Maizena 5\%, 10\% Dan 15\%

\begin{tabular}{lllll}
\hline \multirow{2}{*}{ Perlakuan } & \multicolumn{3}{c}{ Pengulangan } & Rata-rata \\
\cline { 2 - 4 } & \multicolumn{1}{c}{ I } & \multicolumn{1}{c}{ II } & III & \\
\hline P1 5\% & 3,04 & 3,12 & 2,96 & 3,04 \\
P2 10\% & 3 & 3,2 & 3,16 & 3,12 \\
P3 15\% & 3,04 & 3,92 & 3,68 & 3,54 \\
\hline
\end{tabular}

Keterangan : P1 Tepung maizena 10gr : ikan gabus 190gr dengan rata-rata 3,04, P2 Tepung maizena $20 \mathrm{gr}$ : ikan gabus $180 \mathrm{gr}$ dengan rata-rata 3,12, P3 Tepung maizena 30gr : ikan gabus 170gr dengan rata-rata 3,54.

Hasil mutu organoleptik terhadap tekstur menujukan bahwa perlakuan P3 15\% dengan rata-rata 3,5 dengan kreteria (kenyal) dan pada p2 10\% dengan rata-rata 3,1 yaitu (kenyal) pada p1 dengan rata-rata 3,04 yaitu (kenyal). Tekstur masing-masing sampel pada P3 dengan penambahan tepung maizena $15 \%$ dengan rata-rata tertinggi 3,5 dan pada sempel P1 penambahan tepung maizena 5\% dengan rata-rata terendah 3,04.Kekenyalan juga dipengaruhi oleh kadar serat yang terdapat pada tepung maizena yang mampu mengikat air. ${ }^{30}$

Tabel 8 Hasil Analisis Data Tekstur

\begin{tabular}{lll}
\hline Jenis Variabel yang diamati & Sig. & Total rata-rata \\
\hline Tekstur & 0,017 & 3,1 \\
\hline
\end{tabular}

Berdasarkan Tabel 8 menunjukan bahwa uji tekstur ada perbedaan tekstur antara ketiga perlakuan nugget yang dihasilkan. P-value (Sig.) 0,017 ( $<<0,05)$. Adanya pengaruh penambahan tepung maizena terhadap tekstur nugget ikan gabus. Semakin banyak penambahan tepung maizena pada nugget semakin kenyal tekstur nugget ikan gabus yang dihasilkan.

Dari penelitian Ria Kumala Dewi (2015) menyatakan bahwa perlakuan terbaik pada tekstur nugget $10 \%$ penambahan tepung maizena memberikan tekstur yang kompak dan homogen.

\section{Hasil uji kadar protein}

Hasil penelitian kadar protein pada nugget ikan gabus dari penambahan terpung maizena 5\%, 10\% dan 15\% dapat dilihat pada tabel dibawa ini:

Tabel 9 Hasil Kadar Protein Dengan Penambahan Tepung

Maizena 0\%, 5\%, 10\% Dan 15\% Pada Nugget Ikan Gabus

\begin{tabular}{ccccc}
\hline \multirow{2}{*}{ Perlakuan } & \multicolumn{3}{c}{ Pengulangan } & Rata-rata \\
\cline { 2 - 3 } & I & II & III & \\
\hline
\end{tabular}




\begin{tabular}{crrrr}
$\mathrm{P} 1(5 \%)$ & $16,12 \%$ & $15,99 \%$ & $15,48 \%$ & $15,86 \%$ \\
$\mathrm{P} 2(10 \%)$ & $15,96 \%$ & $15,44 \%$ & $15,71 \%$ & $15,80 \%$ \\
$\mathrm{P} 3(15 \%)$ & $15,48 \%$ & $15,38 \%$ & $15,80 \%$ & $15,66 \%$ \\
\hline
\end{tabular}

Keterangan : P1 Tepung maizena 10gr : ikan gabus 190gr dengan rata-rata $15,86 \% \mathrm{P} 2$ Tepung maizena $20 \mathrm{gr}$ : ikan gabus $180 \mathrm{gr}$ dengan rata-rata $15,80 \% \mathrm{P} 3$ Tepung maizena $30 \mathrm{gr}$ : ikan gabus $170 \mathrm{gr}$ dengan rata-rata $15,66 \%$

Berdasarkan Tabel.9 menujukan rata-rata kadar protein nugget berkisar antara 15,66\%$15,86 \%$. Semakin banyak penambahan tepung maizena pada nugget ikan gabus, semakin sedikit kandungan kadar protein pada nugget ikan gabus hal ini disebabkan karena proposi daging yang digunakan semakin berkurang dengan proposi tepung maizena bertambah.

Tabel 10 Hasil Analisis Data Kadar Protein

\begin{tabular}{lll}
\hline Jenis Variabel yang diamati & Sig. & Total rata-rata \\
\hline Kadar Protein & 0,691 & 15,77 \\
\hline
\end{tabular}

Hasil uji menjukan bahwa tidak terdapat perbedaan kandungan kadar protein pada perlakuan P1, P2 dan P3.. Menurut standar mutu nugget (SNI 7758: 2013) tentang nugget ikan, kadar protein minimum 5\%.$^{23}$ Kadar protein nugget ikan gabus hasil penelitian ini sesuai standar SNI nuggetikan yaitu dengan P1 dengan kadar protein 15,86\%, P2 dengan kadar protein $15,80 \%$ dan pada P3 dengan kadar protein 15,66\%. Hasil penelitian ini didukung oleh Desmelati, et al (2014), semakin banyak bahan baku yang digunakan pada pengolahan nugget ikan patin, maka akan semakin tinggi kadar proteinnya dan begitu pula sebaliknya [10].

\section{Hasil uji kadar air}

Kadar air merupakan faktor yang sangat penting dalam bahan pangan karena akan mempengaruhi daya simpannya [11]. Hasil uji kadar air nugget ditampilkan dalam Tabel 11 berikut:

Tabel 11 Hasil Analisis Data Kadar Air

\begin{tabular}{ccccc}
\hline Perlakuan & \multicolumn{3}{c}{ Pengulangan } & \multirow{2}{*}{ Rata-rata } \\
\cline { 2 - 4 } & I & II & III & \\
\hline P1(5\%) & 1,65 & 1,61 & 1,72 & 1,66 \\
P2(10\%) & 1,61 & 1,61 & 1,57 & 1,59 \\
P3(15\%) & 1,63 & 1,51 & 1,50 & 1,54 \\
\hline
\end{tabular}

Kadar air nugget pada perlakuan P1 memiliki kadar air tertinggi yaitu 1,66\%. Hal ini disebabkan karena penggunaan bahan dasar yaitu tahu lebih banyak dibandingkan perlakuan lainnya. Sedangkan P3 memiliki kadar air terendah yaitu 1,54 dibanding dengan perlakuan lainnya. Rendahnya kadar air pada perlakuan P3 kemungkinan disebabkan karena hilangnya sebagian kadar air pada saat proses pengukusan dan penggorengan saat nugget serta penggunaan bahan dasar lebih sedikit dibandingkan perlakuan yang lainnya. Hal ini sesuai dengan penelitian Rifqi (2017) yang menyatakan bahwa pengukusan dilakukan untuk meminimalisir kandungan air dalam bahan pangan [12].

Tabel 12 Hasil Analisis Data Kadar Air

\begin{tabular}{lll}
\hline Jenis Variabel yang diamati & Sig. & Total rata-rata \\
\hline Kadar Air & 0,139 & 1,62 \\
\hline
\end{tabular}


Hasil uji penambahan tepung maizena $(5 \%, 10 \%$ dan $15 \%)$ tidak berpengaruh secara signifikan terhadap kadar air nugget ikan gabus, yang ditunjukan nilai $\mathrm{P}=0,139(\mathrm{P}>0,05)$. Kadar air akan mempengaruhi cita rasa dan tekstur, sebab apabila kadar air tinggi akan mengakibatkan pertumbuhan mikroba sehingga bahan pangan akan mudah rusak dan dapat menyebabkan tekstur lebih lembek dan permukaan ditenganya lebih berair. Fakor yang juga berperan penting dalam penurunan kadar air adalah penggorengan. Proses penggorengan akan menurunkan kadar air produk akibat penguapan atau pembebasan kadar air pada bagian luar produk

\section{KESIMPULAN}

Hasil mutu organoleptik nugget ikan gabus pada porposi tepung maizena terhadap warna adalah memeberi pengaruh nyata terhadap nilai organoleptik (rupa, aroma, rasa, tekstur, dan nilai kadar air, protein yaitu nugget P1 (5\%), pada rasa P1 (5\%), dan Aroma P1 (5\%) dan pada tekstur P3(15\%).hasil penelitian ini sesuai standar SNI nugget ikan yaitu dengan P1 dengan kadar protein $15,86 \%, \mathrm{P} 2$ dengan kadar protein $15,80 \%$ dan pada P3 dengan kadar protein $15,66 \%$, dan kadar air nugget ikan gabus adalah 1,62\%

\section{SARAN}

Diharapkan penelitian ini dapat menjadi acuan penelitian selanjutnya, dalam mengembangkan produk nugget ikan gabus dengan peningkatan nilai gizi lainnya. masyarakat bisa mengembangkan produk nugget dengan memanfaatkan pangan lokal, penulis juga menyarankan untuk melakukan penelitian mengenai masa simpan nugget ikan gabus dan mengidentifikasi jenis bakteri yang terdapat di dalam $\mathrm{p}$ roduk tersebut.

\section{DAFTAR PUSTAKA}

[1] Simanjuntak Agustina Elfrida, Effendi Raswen, dan Rahmayuni. 2017. Kombinasi Pati Sagu dan Modified Cassava Flour (MOCAF) dalam Pembuatan Nugget Ikan Gabus. Jurnal JOM FAPERTA UR Vol. 4 No. 1.

[2] Masrikhiyah, R., \& Octora, M.I., (2020). Pengaruh Kebiasaan Sarapan Dan Status Gizi. Remaja Terhadap Prestasi Belajar. JIGK: Jurnal Ilmu Gizi dan Kesehatan. Vol. 1 (2). 23-27

[3] Badan Standarisasi Nasional. 2013. Nugget ikan, SNI7758-2013. Jakarta: Badan Standarisasi Nasional.

[4] Yuniarti. D.W. dkk. 2012. Pengaruh Suhu Pengeringan Vakum Terhadap Kualitas Serbuk Albumin Ikan Gabus. THPI Studen Journal, Vol. 1 No. 1 pp 1-9 Universitas Brawijaya.

[5] Asrawaty. 2018. Perbandingan Berbagai Bahan Pengikat dan Jenis Ikan terhadap Mutu Fish Nugget. Jurnal Galung Tropika, 7 (1)hal 33-45.

[6] Eny, S.W., Aris S.W., Rery, D.H, dan Made, Y.A. 2010. Kualitas Nugget Ayam dengan Penambahan Keju Gouda. Jurnal Ilmu dan Teknologi Hasil Ternak Hal 1-10.

[7] Ananda Ulandari. 2010. Potensi Protein Ikan Gabus dalam Mecegah Kwashiokor pada Balita di Provinsi Jambi. Jurnal Penelitian Vol. 2 No.1. Halaman 116-117.

[8] Ofrianti dan Wati. 2013. Pengaruh Variasi Kosentrasi Tepung Kedelai sebagai Bahan pengikat Terhadap Kadar Air dan Mutu Organoleptik pada Nugget Ikan Gabus. Jurnal. Poltekkes Kemenkes Bengkulu.

[9] Kumala Dewi Ria. 2011. Kajian Komposisi Kimia Kualitias Fisika dan organoleptik Duck Nugget denga filler Tepung Maizena pada Proposi yang Berbeda.Skripsi. Universitas Sebelas Maret Surakarta.

[10] Desmelati, Sumarto, dan Meilin. 2014. Kajian Penerimaan Konsumen dan Mutu Nugget Udang Rebon (Acetes erythraeus). Jurnal Sains dan Teknologi Pangan, Volume 2(3) : 55- 
56.Haryadi. 2014, Teknologi Mi, Bihun dan Sohun, Gajah Mada University Press, Yogjakarta.

[11] Yuniarti DR., Solikhin A., Fera M. (2020). Uji Organoletik Tepung Ampas Tahu dengan Variasi Lama Pengeringan. JIGK: Jurnal Ilmu Gizi dan Kesehatan. Volume 1 (2): 11-17.

[12] Rifqi A M, 2017. Formulasi Nugget Tahu Pury (Nugget tapury) sebagai Alternatif. Institut Pertanian Bogor, V:22-30. 